\author{
Тетяна Міронова \\ кандидат мистецтвознавства, \\ директор \\ Tetiana Mironova \\ PhD in Art studies \\ director \\ Київської міської галереї мистецтв «Лавра» \\ Kyiv City Art Gallery “Lavra” \\ info@mironova-gallery.com orcid.org/0000-0002-8847-1100

\section{ВИЗНАЧЕННЯ ПОНЯТТЯ «ХУДОЖНЬОЇ ОБРАЗНОСТІ» ТА КОЛА ЇЇ ПОНЯТІЙНОГО АПАРАТУ В СУЧАСНОМУ ОБРАЗОТВОРЧОМУ МИСТЕЦТВІ}

\author{
DEFINITION OF "ARTISTIC IMAgERY" \\ AND ITS CONCEPTUAL APPARATUS IN CONTEMPORARY ART
}

\begin{abstract}
Анотація. Сучасна культура діалогує із суспільством за допомогою художніх образів, що формують загальне поле масової культури. Митці використовують художні засоби, що створюють широкі зовнішні зв’язки, сукупність яких формує особливе середовище - «художній контекст», що стає основою візуальної комунікації. Художній та візуальний образи мають в собі як спільне, так і відмінне: візуальний образ, по суті, є складовою художнього образу і відрізняється від нього певною об'єктивністю та узагальненістю. Сучасні митці нерідко працюють на межі між візуальністю та художнім образом, наповнюючи свої твори різними соціальними та естетичними функціями. Утім, для розуміння художніх образів частіше за все глядач має бути інформаційно та культурно підготовлений, а візуальні образи легко сприймаються широким загалом без такої підготовки. Ключові слова: художній образ, візуальний образ, учасне мистецтво, public art, арт-проект, культурний контекст.
\end{abstract}

Постановка проблеми. У сучасному суспільстві з розвитком нових цифрових та інформаційних технологій відчувається нагальна потреба у швидкому поширенні інформації та знань. Універсальна мова мистецтва блискавично та дуже гостро рефлексує на соціальні та історичні зміни, трансформації суспільних ідеологій уже сотні років, впливаючи на людину пізнаваними та знайомими їй об'єктами - художніми образами. Так, за допомогою художніх образів сучасна культура діалогує із суспільством, формуючи загальне поле масової культури.

Ще починаючи з часів постмодерну, коли мистецтво повністю вийшло за межі ритуальних та символічних функцій, митці активно використовують художні образи, що часто стають їх своєрідною візитівкою, висуваючи на перший план комерційну та утилітарну складову. Так, постійний відвідувач сучасних виставок легко впізнає та зчитує знайомі образи, притаманні тому чи іншому автору, і протягом всього творчого життя художника може дослідити розвиток його художньої мови, що розкривається в історичній перспективі, а не одноразово, в моменті.

Огляд останніх досліджень і публікацій. Пришвидшення темпу життя привело до зміни мови суспільних комунікацій: з вербальної - на візуальну. Це інспірувало чимало наукових досліджень як проблеми художнього образу, так і понятійного апарату усієї сфери візуального. Дослідження специфіки художнього образу в мистецтві кінця XX - початку XXI століття відбувалося із залученням різних контекстів та методик такими науковцями, як Р. Арнхейм, Б. Ананьєв, М. Берштейн, Л. Веккер, Л. Виготський, П. Гальперін, В. Зинченко, А. Леонтьєв, С. Рубінштейн та ін. В історичному контексті психологічне вивчення образу відбувалося паралельно із зародженням та становленням психології як науки, позаяк перші принципові позиції дослідження образу були закладені ще в античній філософії [4, c. 90]. У психологічній науці категорію образу розглядали ледь не всі психологічні напрями. I сьогодні до образу часто звертаються різні методики і практики [9, с. 154]. При цьому невизначеність дослідницьких завдань, відсутність чіткої логіки та «заангажованість» багатьох науковців значно уповільнюють цей процес та лишають поза увагою мистецтвознавчої науки проблемні питання розуміння художнього образу.

Виклад основного матеріалу. Художній образ. Митці за своєю природою гостріше за інших реагують на навколишні обставини, використовують у творчості знайомий багатьом арсенал творчих засобів, підіймаючи ïx до рівня художнього образу. Упродовж століть існування мистецтва автори збагачують власну образність засобами візуального, 
що відповідно до загальних тенденцій світоустрою постійно оновлюються. При цьому вони незмінно залишаються інформаційно зрозумілими та лаконічними, адже художній образ, при здатності поєднувати кілька сенсів, все ж таки має залишатись конкретним і компактним, як найшвидший та точний засіб передачі інформації до реципієнта.

Усі мистецькі об’єкти, чи то традиційні скульптура, живопис чи графіка, чи нові медійні мистецтва, постають у реальності насамперед у свідомості художника, який спочатку «виношує» ідею або образ, а потім втілює в тій чи іншій техніці. При цьому художній образ, який вони транслюють у реальність, виконує свою соціальну функцію тільки за наявності естетичної комунікації у сучасному йому суспільстві. А сьогодні, створюючи художні образи, митці не завжди намагаються зробити їх зрозумілими та доступними для глядача. Тож художній твір, взятий сам по собі, без визначеного культурного чи історичного контексту, без розуміння реципієнтом системи культурних символів та кодів, за висловом Ю. Лотмана, стає «подібним до напису на надгробку іноземною мовою» [6, c. 207]. Кожен художній образ як акт художньої комунікації виникає на межі об’єктивного та суб’єктивного, завжди маючи на увазі не лише особистість його автора, а й певну групу глядачів, які розуміють визначену знакову систему. Крім того, художні образи доволі часто створюють та використовують як засоби впливу на суспільство. Від діапазону сприйняття суспільством системи знаків та символів, вкладених автором у мистецький твір, і залежить сила впливу художнього образу, що має: викликати у глядача внутрішній діалог; узагальнювати (бути в актуальному контексті сучасності); викликати емоції та почуття; утримувати стійкий інтерес глядача [9, с. 153]. Сукупність цих факторів (за С. Даніелем - «сукупність умов розуміння» - прим. наша) обумовлює життєздатність художнього образу, виразність його суспільноі комунікації. Від сили впливу кожного з них та завдяки гармонійному співіснуванню знаків та символів у мистецькому творі залежатиме його значущість в історії мистецтва або навпаки - одноденність. Адже твори мистецтва, створені не на часі, неактуальні або без ідеї, яка б відгукувалася в глядача - не будуть виконувати комунікаційної функції і стануть лише декоративним об'єктом. Відсутність художнього образу в мистецькому творі робить його нецікавим для глядачів.

Головні запитання, що має ставити глядач: як художник творить і навіщо? А завданням художника є відповідь на ці питання. I ці відповіді часто бувають значно цікавіші, ніж сама робота. Водночас таке мистецтво вимагає від глядача певних знань та рівня свідомості: позаяк за своєю природою мистецтво сприймається зором - за його формою неодмінно ховається непомітна змістовна складова, що зазвичай передає значно більше ін- формації, ніж здається на перший погляд. Саме наявність цієї складової проявляє тенденцію до формалізації змістовних елементів, до їхнього своєрідного застигання, перетворення на штампи, а відтак - повного переходу зі сфери візуального в умовну систему універсальних знаків та кодів [6, с. 12]. Знакова система сучасного мистецтва, завдяки доволі глобалізованому арт-простору, значно більш доступна та конкретна, порівняно 3, наприклад, голландським та фламандським живописом XVII століття. Вона легко перетинає межі країн та навіть континентів, формуючи загальні світові тенденції культурно-мистецького розвитку, спираючись на візуальні образи, символи і знаки.

У багатьох художників створені ними художні образи стають прозивними та отримують своє власне існування, живучи наче паралельно з самим автором. Приміром, створений майже 30 років тому Віктором Сидоренком образ транзитивної людини «героя/об’єкта/фантома» (як його визначає сам художник) - у сприйнятті мистецтвознавців та критиків живе новим, не передбаченим автором життям, породжує нові значення і змісти. За твердженням О. Аккаш, «візуальний образ людини-в-спідньому усуває скептицизм з приводу соціальних функцій мистецтва, наочно візуалізуючи його комунікативну роль у підтримці соціальної пам'яті й їі індивідуації, не абсолютизуючи минуле і не ідеалізуючи майбутнє» [10, с. 39]. Автор сам зізнається, що як глядачі, так і колеги використовують його образи абсолютно в інших контекстах, наприклад «образи проекту “Жорна часу”, показаного на Венеційській бієнале (2003), було сприйнято багатьма глядачами як пам'ять про Голодомор в Україні або про трагедію Чорнобиля. Для мене ж тут ішлося не про конкретні історичні події, а про драму часу, котрий маніпулює окремим людським життям, розчиняє особистість у черговому ідеологічному проекті» [10, с. 42]. На противагу художнику, який наповнює свій персонаж глибоким філософським змістом, дослідники наділяють персонаж В. Сидоренка божественними рисами, надають йому ознак пророка, а інколи сприймають його генезу в контексті розвитку мистецтва як перформативне дійство. Використання одного персонажа в різних послідовних серіях в естетичній системі Віктора Сидоренка - наскрізне та природне. Воно завжди, залежно від авторського задуму, є діалектично складною аналогією з його життям. На кожному етапі свого послідовного розвитку герой/об'єкт/фантом постає перед глядачем по-новому [6, с. 210].

Проекти «Шахтарський фольклор», «План втечі $з$ Донецького регіону» (2007 - дотепер) - своєрідний автобіографічний епос для художника Романа Мініна. У творчих людей стан повноти життя часто синонімічний професії. У самого Романа та героїв його творів, втілених в образах шахтарів, як каже сам художник, «є щось спільне: адже художник 
брудниться у фарбу, а шахтар - у вугілля. Обоє копаються: художник - усередині себе, шахтар - у землі» [8]. Під час дослідження творчості Романа стає зрозумілим, що це той випадок, коли художній образ сам обрав художника. Для створення робіт йому, як представнику донецького регіону, не потрібно було щось досліджувати або витрачати час на збирання матеріалів, адже він виріс у шахтарській родині і цю тему знає дуже добре. Роман використовує в роботах знайомі глядачу візуальні образи: у серії робіт «Свій - Чужий» він поєднав образ ксеноморфа (інопланетна істота з фільму «Чужий») 3 шахтарем як стереотипним символом Донецької області, підкреслюючи, що багато людей з цього регіону сьогодні сприймаються «чужими». Сьогоднішній успіх робіт Мініна став результатом довгого творчого шляху - від різкої критики чиновників та закриття виставок до вдалих продажів на найкращих світових аукціонах. Образ шахтаря в його творчості завжди пов'язаний 3 його життям, є реакцією на зовнішні події. Художник змінює техніку створення, експериментує з матеріалами та контекстом, надаючи своєму художньому образу багатогранності та розширюючи змістовність.

Художніми образами фотопроекту Сергія Мельниченка «SUPERHEROES» (2014-2015) стали знайомі кожному популярні персонажі комп'ютерних ігор, «поєднані» автором із реальними людьми на вулицях. Таким чином художник ставить запитання: «Хто є Героєм нашого часу? Який він? Які його якості? Що таке героїзм? Що таке подвиг? Чи він актуальний сьогодні?». Художній образ «героя» Сергія Мельниченка - не ідеальний, він може бути некрасивим, худим, не працьовитим, суперечливим, продуманим, неуважним. У кожної людини — різні герої. Для одних — це ті, хто вершить подвиги, жертвують собою в ім'я якихось світлих ідей або для порятунку від небезпеки, для інших - прості люди, які говорять правду і живуть за справедливістю в той час, коли брехня та зрада є буденними явищами. У творчості художника герої - універсальні, вони створюються в уяві та одночасно існують у підсвідомості людини, утворюючи асоціативний ряд - таким чином один і той же образ може виглядати по-різному. Для втілення цього розмаїття Сергій Мельниченко ототожнює сучасних вуличних «перехожих" із героями коміксів та популярних кінофільмів. Сила глибини художнього образу тут досягається за допомогою прирівняння абстрактних моделей до найбільш неочікуваних, не схожих на них у реальному житті. А засоби фотографії дозволяють художнику імпровізувати, проявити естетику тотожності, висуваючи на одному полюсі традиційні системи персонажів, сюжетних схем та інших структурних елементів, а на другому - рухливу форму художньої творчості [6, с. 210].

Так митці використовують художні засоби, що створюють широкі зовнішні зв'язки, сукупність яких формує особливе середовище, особливу атмосферу твору, іншими словами, «художній контекст», що містить композицію як «ядро» художньої комунікації. Мистецтво хоч і звертається до життя, втім, не є його простим відображенням, воно загострює, опрацьовує та віддає життєву енергію, утворюючи навколо себе живий простір, наповнений змістом [4, с. 150]. Художні образи є чітко спланованими та продуманими концепціями, їхній розвиток має свій сценарій, який часто залежить від історичних та культурних обставин. В тому чи іншому вигляді вони постійно виринають у творчості митців, формуючи психологічне звикання глядачів, а відтак і упізнаваність художників серед великої кількості мистецтва у сучасному арт-середовищі.

Візуальний образ. Більшість людей сприймає та пізнає навколишній світ за допомогою візуальних образів. У сучасному мистецтві візуальний образ існує паралельно з художнім, втім, у мистецтвознавчій науці він більше асоціюється $з$ мистецтвом public art. Сьогодні перенасичення інформаційного поля людини арт-об’єктами вже зробило їх частиною життєвого простору. По суті, об’єкти візуального мистецтва є певними художніми формами, що крім естетичного набувають утилітарного змісту, зрозумілого широким масам. Втім, за визначенням В. Беньяміна, в цьому випадку «маси - це матриця, звідки будь-який звичний твір мистецтва виходить переродженим. Кількість переходить у якість: маси учасників призвели до зміни способу участі. Не варто звертати увагу, що першопочатково їхній образ дещо дискредитується. < ... > по суті, це стара скарга, що самі шукають розваг, в той час як мистецтво вимагає від глядача концентрації. < ... > Розвиток і концентрація складають протилежність, що дозволяє сформулювати таке твердження: той, хто концентрується на мистецькому творі, заглиблюється в нього - заходить у цей твір подібно до художника - героя китайської легенди, який споглядає свою завершену роботу. Тим часом маси, що розважаються, навпаки, занурюють твори мистецтва в себе. Найбільш показовою у цьому сенсі $є$ архітектура, яка віддавна була прототипом мистецького твору, сприйняття якого не вимагає концентрації та відбувається в колективних формах» [1, с. 66-91]. Грань між образами візуальними та художніми - досить тонка, вона балансує на межі мистецтва та дизайну, і часто ці два поняття використовують як рівнозначні. Утім, художній образ $€$ ширшою категорією, що працює з філософським контекстом та потребує від рецепієнта певних знань, тоді як образ візуальний $є$ часто тільки повсякденним посередником-ретранслятором між художником та глядачем, максимально зрозумілим більшості.

Термін «візуальне мистецтво» («arts visuells» («visual arts») вводить мистецтво у поле реальності - прим. наша) сформувався в епоху постмодерну і означає вид художньої творчості, що поєднує традиційні форми мистецтва та новітні зображальні техніки та при- 
кладні декоративні форми, які фокусуються на візуальних образах і спрямовані на емоційнопочуттєве сприйняття. Це мистецтво насамперед засноване на концептуальному мисленні, воно, за переконанням дослідника Д. Бакер та куратора Ральфа Ругоффа, визначає «ідею переосмислення просторового сприйняття людини і навколишнього середовища через концепт візуального мистецтва» [11]. При цьому Ругофф наголошує на необхідності переосмислення не лише понятійно-категоріального апарату сучасних візуальних мистецтв, а й власне ставлення до категорії простору та можливостей взаємозв’язків та взаємодій простору [11; 12, с. 11]. Таке твердження порушує питання необхідності дослідження мистецтва public art у контексті розвитку суспільства, позаяк його основними функціями є просвітницька та інформаційна, а вже потім естетизація міського простору. Iнноваційні форми роботи з простором викликають оновлення розуміння онтологічних основ мистецтва на нових соціокультурних рівнях. I. Мальковська зазначає, що «різко зросла доступність видів та об’єктів інформації; інтернет-комунікації змінюють уявлення про простір і час; розгорнулася універсалізація шоу-культури, що породжує нові уявлення про дозвілля, вільний час, самореалізації, самопрезентації; змішання культур створює транскультурного мислення і т. ін.» [7, с. 46]. Митці, які працюють із візуальними образами, для створення своїх арт-об’єктів сьогодні послуговуються тими ж художніми засобами, що і класичне мистецтво, з підкресленим акцентом на технологію та «зробленість» (майстерність). Так, за визначенням В. Власова, «термін “візуальний” необхідно застосовувати не до художніх, а до технічних видів діяльності та до естетико-технологічних способів формотворення, як-от дизайн, стайлінг або мистецтво оформлення» [2, с. 196-197]. Саме так характеризують публічні мистецтва, створені для вуличних та громадських просторів - міських парків, суспільних та культурних центрів, прибудинкових територій. Ці об’єкти мають функціональне навантаження, зокрема формують міський простір, обігруючи зовнішні комунікаційні системи, відіграючи роль об’ємних пластичних об'єктів, спеціальних знаків-символів [3]. Таке публічне мистецтво дедалі частіше виходить за межі галерей, ярмарків та виставок, займає місце у повсякденному житті людини. Утилітарна функція візуального образу зумовила його тиражність та повторюваність, а також певну матеріальність: адже твори public art $€$ більше «об'єктами», ніж «художніми творами» в традиційному розумінні. Прикладом застосування візуальних образів у міських просторах у сучасному українському мистецтві $€$ роботи Єгора та Микити Зігур - молодих скульпторів, авторів інсталяцій та арт-об'єктів, творчість яких відома як в Україні, так і за кордоном. Обидва художники працюють з актуальними сьогодні темами - збереження до- вкілля, людських стосунків, розкриваючи інші проблеми глобального суспільства: ідентифікацію у мультикультурному світі, консюмеризм та ін.

Великі, складні у виконанні об’єкти брати створюють зазвичай разом. Нестримний рух уперед, прагнення до нового і кращого, розвиток та творення, отримання інформації та мотивація - все це втілилось у металевому скульптурному об’єкті «R/Evolution», що був встановлений Єгором та Микитою Зігурами у Дніпрі біля приватної клініки "А2 clinic» (2020). Арт-об'єкт виконано зі зварених між собою полірованих прутів і труб з нержавіючої сталі, їхня загальна кількість складає понад 1000 одиниць. Саме за допомогою обраного методу формотворення художникам вдалося візуалізувати процес руху. У схожій техніці створено скульптурну композицію «Єднання» (2020), встановлену в Києві на Дніпровській Набережній. Ідея твору не обмежується тілесним виміром: йдеться про розчинення одна в одній двох протилежностей, і водночас про формування кожної людини як цілісної особистості через проникливу, емпатичну взаємодію. Скульптура «Ская. Телепортація», встановлена в просторі клубу «SkyBar» у Києві - сповнена жіночності та привабливості, іï силует наче заряджає простір позаземною енергією, що рухається поміж сторінок історії, залишає нашу планету у пошуках істини або, можливо, повертається 3 новими знаннями про Всесвіт [5].

Проблема забруднення світового океану чи не найактуальніша зараз тема дискусії для людей, що опікуються долею планети. Сотні зникаючих видів флори і фауни, кілометри сміття, острови пластику. Митці не можуть залишатись осторонь, пропускаючи крізь себе навколишню дійсність, i, можливо, знайдуть альтернативний шлях порятунку. «Медуза LDPE» (з проекту «Нова Археологія»), створена братами для виставки «Середовище існування. Маніфест 2020» (галерея «Лавра», 2020), скульптура, що «народилася 3 вторинного, зайвого, шкідливого. LDPE - маркер поліетилену низької щільності. Те, що було брудом, непотребом, що люди викидали, наче саме не згодне з таким варварством, тож створює нове, знищене через нього життя" (з авторської концепції - прим. наша). Тему збереження довкілля скульптори розвивають у лаконічних та яскравих композиціях «Рівновага» та «Райський Гранат» (2017).

Брати Єгор та Микита Зігури вдало працюють 3 різними контекстами, створюючи свої арт-об'єкти у інноваційних формах та технологіях. У своїй творчості митці досліджують багатогранність і неоднозначність людської особистості, ставлячи її у центр своїх художніх, інтелектуальних і філософських пошуків. Автори поєднують традиційні та сучасні матеріали, зробивши своєю головною метою досягнення плідного балансу між активним творчим розвитком та гармонією з довкіллям.

Висновки. Художні образи - мистецькі 
засоби, призначені для трансляції та передачі інформації - мають бути завжди доступними та зрозумілими великій кількості глядачів. В епоху цифрових технологій та швидкого темпу життя культура змінює орієнтацію з вербальної комунікації на візуальну, отже головним завданням художнього образу стає візуальний спосіб передачі інформації та комунікація з глядачем на рівні певного культурного прошарку. Художні образи нерозривно пов'язані з митцями, їхнім світосприйняттям та культурним контекстом, вони завжди поза межами простого зображення дійсності і $є$ більш елітарними за своєю природою. Водночас у сучасному мистецтві розвивається напрям public art, що за своєю природою звертається до широких мас суспільства зрозумілою та знайомою йому візуальною мо- вою. Арт-об'єкти, створені митцями в публічних просторах, комунікують із глядачем, візуалізуючи задуману художниками інформацію або ідею.

Тож художній та візуальний образи мають в собі як спільне, так і відмінне: візуальний образ, по суті, є складовою художнього образу і відрізняється від нього певною об'єктивністю та узагальненістю. Сучасні митці нерідко працюють на межі між візуальністю і художнім образом, наповнюючи свої твори різними соціальними та естетичними функціями. Утім, для розуміння художніх образів частіше за все глядач має бути інформаційно та культурно підготовлений, а візуальні образи легко сприймає і широкий загал без такої підготовки.

\section{Література}

1. Беньямин В. Произведение искусства в эпоху его технической воспроизводимости. М., Медиум, 1996. С. $66-91$.

2. Власов В. Визуальное мышление, визуальные искусства // Большой энциклопедический словарь изобразительного искусства: в 8 т. СПб.: ЛИТА, 2000. Т. 1. С. 196-197.

3. Гончаренко А. Трансформації розвитку української скульптури (в контексті культурно-мистецьких процесів 1990-х - 2000-х рр.) // Дис. ... канд. мист. 26.00.01. Теорія та історія культури. Івано-Франківськ, 2015.

4. Даниэль С. Искусство видеть. СПб., 2006., с. 150.

5. Кулікова В. Мистецтво у нічному клубі: бачення Єгора та Микити Зігури https://artslooker.com/mistectvo-u-nichnomu-klubi-bachennya-iegora-ta-mikiti-ziguri/

6. Лотман Ю. Об искусстве: Структура художественного текста. Семиотика кино и проблемы киноэстетики: Статьи. Заметки. Выступления (1962-1993). СПб., 1998. с. 207.

7. Мальковская И. Визуальная культура: проблемы самоидентичности // Гуманитарные науки: теория и методология. 2008. № 4., с. 46.

8. Прокопенко М. Художник Роман Мінін: «У кожного є свій план втечі» http://www.golos.com.ua/article/50719

9. Серикова Т. Трансформация понятий «визуальный» и «художественный» образы в современной культуре // Известия Алтайского государственного университета, 2010. С. 152-155.

10. Сидоренко В. Герой, Об’єкт, Фантом Віктора Сидоренка: Лексикон. Київ: ArtHuss, 2019. С. 39.

11. Rendell J. Art and Architecture: a Place Between. New York: I. B. Tauris\& Co. Ltd., 2006.

12. Rendell J., Rugoff R. Dillon, Brian. Psycho Buildings, London, Hayward Publishing, 2008. P. 11.

\section{References}

1. Benyamin V. Proizvedenie iskusstva v epohu ego tehnicheskoy vosproizvodimosti. M., Medium, 1996. S. 66-91.

2. Vlasov V. Vizualnoe myishlenie, vizualnyie iskusstva // Bolshoy entsiklopedicheskiy slovar izobrazitelnogo iskusstva: v 8 t. SPb.: LITA, 2000. T. 1. S. 196-197.

3. Goncharenko A. Transformaciyi rozvy`tku ukrayins `koyi skul `ptury` (v konteksti kul `turnomy`stecz `ky`x procesiv 1990-x - 2000-x rr.) // Dy`s. ... kand. my`st. 26.00.01. Teoriya ta istoriya kul `tury`. Ivano-Frankivs`k, 2015.

4. Daniel S. Iskusstvo videt. SPb., 2006., s. 150.

5. Kulikova V. My`stecztvo u nichnomu klubi: bachennya Yegora ta My`ky`ty`Zigury` https://artslooker.com/mistectvo-u-nichnomu-klubi-bachennya-iegora-ta-mikiti-ziguri/.

6. Lotman Yu. Ob iskusstve: Struktura hudozhestvennogo teksta. Semiotika kino i problemyi kinoestetiki: Stati. Zametki. Vyistupleniya (1962-1993). SPb., 1998. s. 207.

7. Malkovskaya I. Vizualnaya kultura: problemyi samoidentichnosti // Gumanitarnyie nauki: teoriya i metodologiya. 2008. \# 4., s. 46.

8. Prokopenko M. Xudozhny`k Roman Minin: «U kozhnogo ye svij plan vtechi» http://www.golos.com.ua/article/50719.

9. Serikova T. Transformatsiya ponyatiy «vizualnyiy» $i$ «hudozhestvennyiy» obrazyi v sovremennoy kulture // Izvestiya Altayskogo gosudarstvennogo universiteta, 2010. S. 152-155.

10. Sy`dorenko V. Geroj, Ob'yekt, Fantom Viktora Sy`dorenka: Leksy`kon. Ky`yiv: ArtHuss, 2019. 240 c. S. 39.

11. Rendell J. Art and Architecture: a Place Between. New York: I. B. Tauris\& Co. Ltd., 2006.

12. Rendell J., Rugoff R. Dillon, Brian. Psycho Buildings, London, Hayward Publishing, 2008. R. 11. 


\section{Mironova T.}

Definition of «artistic imagery» and its conceptual apparatus in contemporary art

Contemporary culture conducts a dialogue with society through artistic images that form a common field of mass culture. Artists use techniques to create some broad external relations, the totality of which forms a special environment - «art context», which becomes the basis of visual communication. Artistic and visual images have in themselves both common and different: the visual image, in fact, is part of the artistic image and differs from it in a certain objectivity and generalization. Contemporary artists often work on the border between visual and artistic way, filling their works in various social and aesthetic functions. However, for the understanding of artistic images the viewer often has to be informative and culturally prepared, and visual images easily perceived by the public without such training. Artistic images - means intended for broadcasting and transmitting information - must always be accessible and understandable to a large number of viewers. In the era of digital technologies and the fast pace of life, culture changes its orientation from verbal communication to visual, so the main task of the artistic image is the visual way of conveying information and communication with the viewer at the level of a certain cultural layer. Artistic images are inextricably linked with the artists, their worldview and cultural context, it is always a simple depiction of reality and are more elitist in nature. At the same time, contemporary art develops the direction of "public art», which by its nature refers to the broad masses of society clear and familiar to his visual language. Art objects created by artists in public spaces, «communicate» with the audience, the artists conceived visualizing information or idea.

Keywords: artistic image, visual image, contemporary art, public art, art project, cultural context.

\section{Миронова Т. В.}

Определение понятия "художественной образности" и ее понятийного аппарата в современном изобразительном искусстве

Современная культура ведет диалог с обществом с помощью художественных образов, которые формируют общее поле массовой культуры. Художники используют методы, создающие широкие внешние связи, совокупность которых формирует особую среду - «художественный контекст», который становится основой визуальной коммуникации. Художественный и визуальный образы имеют в себе как общее, так и различное: визуальный образ, по сути, является частью художественного образа и отличается от него определенной объективностью и обобщенностью. Современные художники нередко работают на границе между визуальностью и художественным образом, наполняя свои произведения различными социальными и эстетическими функциями. Впрочем, для понимания художественных образов чаще всего зритель должен быть информационно и культурно подготовлен, а визуальные образы легко воспринимаются общественностью без такой подготовки.

Ключевые слова: художественный образ, визуальный образ, современное искусство, public art, арт-проект, культурный контекст. 